\title{
MEALYBUGS AND THEIR PARASITOIDS IN NELSON PIPFRUIT ORCHARDS
}

\author{
D.R. WALLIS and P.W. SHAW \\ The New Zealand Institute for Plant \& Food Research Limited, Motueka 7189, \\ New Zealand
}

Corresponding author: RWallis@hortresearch.co.nz

Three species of mealybug are major pests on a wide range of horticultural crops in New Zealand, Pseudococcus longispinus, $P$. calceolariae and $P$. viburni. They can be found throughout New Zealand, although they rarely become pests south of Marlborough. Because colonies often establish in the calyx and stem of developing fruit, they can cause rejection of export fruit. During the 2008 Nelson apple harvest, an increase in mealybug numbers was recorded for some commercial orchards. A sample of 58 mealybug-infested apples was kept in a climate chamber at $20^{\circ} \mathrm{C}$ to determine if any parasitoids were present. From these, 16 Tectracnemoidea sydneyensis (Hym: Encyrtidae) and two Coccophagus gurneyi (Hym: Aphelinidae) parasitoids were reared. The following season, 5400 fruit were examined from an infested block to determine mealybug species and the level of fruit infestation. $18.8 \%$ of the fruit were infested, $15.5 \%$ by P. longispinus and $1 \%$ by P. calceolariae. Another 89 infested fruit were kept in individual containers at $20^{\circ} \mathrm{C}$. From this sample, 308 mealybugs were counted, of which 305 were $P$. longispinus and three were $P$. calceolariae. Fifteen percent of the $P$. longispinus were parasitised by $T$. sydneyensis. Results from this study confirmed that $P$. longispinus was the predominant mealybug species and that $T$. sydneyensis was the most common parasitoid.

\section{EFFECT OF PRE- AND POST-BLOSSOM INSECTICIDE RESIDUES ON EUROPEAN EARWIG, FORFICULA AURICULARIA, IN KIWIFRUIT}

\author{
B.J. MAHER ${ }^{1}$ and P.G. CONNOLLY ${ }^{2}$ \\ ${ }^{1}$ The New Zealand Institute for Plant \& Food Research Limited \\ (Plant \& Food Research), 412 No. 1 Rd, Te Puke, New Zealand \\ ${ }^{2}$ Plant \& Food Research, Private Bag 92169, Auckland, New Zealand \\ Corresponding author: bmaher@hortresearch.co.nz
}

In kiwifruit orchards the European earwig, Forficula auricularia L., can be a useful predator of scale insects. However, insecticide use may reduce earwig numbers and previous work indicated that diazinon residues caused high mortality of earwigs. Diazinon has been replaced by several insecticides in the crop protection programme. In this study, late instar earwigs, which are the stages found in the canopy prior to flowering, were exposed to residues of pre-blossom insecticides, thiacloprid $\left(\right.$ Calypso $\left.{ }^{\circledR}\right)$, thiamethoxam $\left(\right.$ Actara $^{\circledR}$ ) and spirotetramat (Movento ${ }^{\circledR}$ ), following spray applications in spring. Adult earwigs were exposed to residues of chlorpyrifos (Lorsban ${ }^{\circledR}$ ) following an application in March when adults only are present in vines. One earwig was placed in each of thirty Petri dishes, three vines per treatment, with two 5 - $\mathrm{cm}$ cane segments cut from sprayed vines and kept at $20^{\circ} \mathrm{C}$. Relative to controls there was no additional mortality of earwig nymphs following exposure to pre-blossom insecticide residues from 1-15 days after spraying. All adult earwigs survived one night's exposure to chlorpyrifos residues, but after five successive nights mortality ranged from 10 to $90 \%$ up to 7 days after spraying, suggesting an accumulative response. 